\title{
The effectiveness of Shariah supervisory board on super- vision and counselling in Shariah rural bank Mitra Ca- haya Indonesia Yogyakarta
}

\author{
Selamat Muliadi ${ }^{1 *}$, Nur Feriyanto ${ }^{2}$ \\ 1, 2 Islamic University of Indonesia, Yogyakarta, Indonesia
}

\author{
Keywords \\ Effectiveness \\ Shariah supervisory board \\ National Shariah board \\ Indonesian ulema council \\ Shariah rural bank
}

Received: 26 October 2017 Accepted: 8 January 2018 Published: 13 February 2018

\begin{abstract}
Islamic banks underlie the fundamental principles of Shariah, encompassing all business activities, financial contracts, and transactions. The Shariah Supervisory Board (SSB) plays an important role in the Islamic banking system, and it has an important impact on their performance and stability. The obedience of Shariah is an obligation that must be implemented by each bank based on Shariah. The research aims to determine the effectiveness of supervision and counseling in the implementation of Shariah principles by the SSB in Shariah Rural Bank Mitra Cahaya Indonesia Yogyakarta. As an independent agent of the National Shariah Board-Indonesian Ulema Council works overseeing and has a big responsibility. In overseeing the new product, the SSB took several steps, i.e., first, the SSB asked for an explanation from the board of directors of the new products that will be issued. Second, check if the new product is following Islamic principles. Third, give an opinion on Shariah's new product. This study uses a qualitative approach with descriptive data. Data were obtained through interviews, observation, and literature review. The study concluded that the SSB is a significant department in Shariah Rural Bank Mitra Cahaya Indonesia Yogyakarta, like the other departments. The interference in decision-making and management could adversely affect the Shariah Rural Bank Mitra Cahaya Indonesia Yogyakarta. In general, the supervision by the SSB in Shariah Rural Bank Mitra Cahaya Indonesia Yogyakarta has been effective because the SSB not only does the good supervision but also makes improvements and developments. The SSB monitors with his best ability and prioritizes the Shariah Rural Bank Mitra Cahaya Indonesia Yogyakarta.
\end{abstract}

(c) 2018 The Author(s). Published by TAF Publishing.

\section{INTRODUCTION}

\section{Background}

Bank Indonesia (Indonesian Central Bank) plays a significant role in the development of Islamic banking in Indonesia by providing banking regulatory and legal framework. The latest regulation encouraging Islamic banking was the Banking Act No.21 issued on July 2008, applicable to Islamic Commercial Banks, Islamic Business Units and Islamic Rural Banks. This Act has provided a more adequate legal base for the development of Islamic banking in Indonesia, and it is expected to speed up the growth of the industry. Islamic banking refers to a system of banking or banking activity that is consistent with the principles of Shariah and its practical application through the development of Islamic eco- nomics. Islamic banks have past been predominantly practiced in the countries with large Muslim populations.

Islamic financing or interest-free financing has experienced a rapid growth and is now practiced world wide in Muslim and non-Muslim countries. To ensure that the product offered to clients fulfill the criteria of being halal (acceptable under Islamic law) Islamic financial institutions seek advice of Muslim scholars. These scholars are known as Shariah advisers and usually part of SSB. Members of the SSB shall meet requirements of integrity, competence and financial reputation. Integrity requirements are those with good moral and character, those committed to complying with applicable legislation, those with high commitment to the development of a healthy bank operation and which are

${ }^{*}$ corresponding author: Selamat Muliadi

†email: selametmuliadi@gmail.com 
on the list pass in accordance with the provisions stipulated by the Bank Indonesia (Indonesian Central Bank). The competenc requirements are those who have knowledge and experience in the field of Shariah muamalah, knowledge banking and finance general. The purpose of Shariah muamalah is social relations, including business activities, which are in line with or based on Shariah principles. The terms of financial reputation are those that are not included in the list of non-performing financing (Antara, Musa, \& Hassan, 2016; Jundiani, 2009).

In implementation of the process and guidance the SSB in Shariah Rural Bank Mitra Cahaya Indonesia Yogyakarta gives only compliance supervision product where it can be seen that object supervisory material is all the Islamic banking products even up to reporting stage of the SSB to the National Shariah Board-Indonesian Ulama Council, Directors, Commissioners and Indonesian Central Bank only contains the results of its supervision to product/service and business activities of a Shariah Rural Bank Mitra Cahaya Indonesia Yogyakarta. Therefore, there needs a system supervision and the SSB explicitly lists coaching objectives, so the reporting SSB include results of guidance that has been done (Umam, 2015). As for internal coaching in Shariah Rural Bank Mitra Cahaya Indonesia Yogyakarta by SSB formally against all employees in Shariah financial institutions and external coaching such as socialization and education either to community or between other Shariah Rural Bank formally either in the form of seminar or other events such as recitations, Friday prayers, teaching on campus, boarding schools and others. In carrying out it operations Shariah Rural Bank must have conformity with Shariah principles. SSB is independent institution granted mandate by National Shariah Board to oversee operational and practice Shariah Rural Bank towards Shariah compliance (Hidayati, 2008). The first observation by the author in Shariah Rural Bank Mitra Cahaya Indonesia Yogyakarta obtained some basic information. Among them is that Shariah Rural Bank Mitra Cahaya Indonesia Yogyakarta have two SSB. in addition to work as SSB in Shariah Rural Bank Mitra Cahaya Indonesia Yogyakarta, SSB also have a job others like taking care of the boarding school they have. So, that as members of SSB is not the only job they are pursuing right now. This will effect the intensity of SSB in office. As a SSB appointed by the National Shariah Board should take full responsibility for supervision in Shariah Rural Bank Mitra Cahaya Indonesia Yogyakarta. It does not rule out that deviation or errors in transactions will occur every day while SSB is located at least once a week. Then it can be concluded that the implementation of supervision by SSB has not been well imple- mented especially in the system of applying routine schedule of SSB, so that the routine still has to be corrected again. Knowing of the issues related to effectiveness of supervision and counselling in Shariah Rural Bank Mitra Cahaya Indonesia Yogyakarta by the SSB. The author intends to investigate the important part of Shariah governance framework i.e., SSB. Fulfillment of this objective is the novel contribution of this study, which shall beneficial for all the stakeholders including policy makers to develop and improve better supervision mechanism in the existing SSB.

\section{LITERATURE REVIEW}

This nomination and election process leads to practice of the SSB being dependent on the board of directors and shareholders. So when the SSB members are interested in continuing their mandates (being reelected) (Farook \& Farooq, 2011). So, the SSB is subject to a conflict of interest between Shariah governance and economic success of a bank. The secondary sources of Shariah are especially relevant to the certification and monitoring. They allow scope in the interpretation and transformation, so that the SSB members can differentiate beyond strictly prohibited (Haram) and permissible (Halal) elements (Al-'layat, 2006; Madiawati \& Pradana, 2016). According to the model of Adams and Ferreira (2007), less independent SSB may decide the interest of management and shareholders under the as sumption that both share the same motives and it may not monitor management too intensively (Hermalin \& Weisbach, 2001). As mentioned in the introduction, the causal relationship between board characteristics and firm attributes is a key issue in this research field. Thus, if the structure of the SSB impacts firm's specific measures (risk-taking, performance) rather than on the contrary is the most relevant endogeneity problem. Most studies analyze one direction of the causal relationship, working hard to find the most suitable econometric method to handle endogeneity issues. In our study, we achieve additional robustness by examining reverse direction of our primary research question in terms how individual bank determinants (risk-taking, performance) influence the composition of the SSB. To our knowledge, this is the first study with this research approach that focuses entirely on Islamic banks based in Indonesia.

We examine, the disciplinary effectiveness of the SSB, according to legal, institutional and regulatory systems of Shariah Rural Bank in Indonesia that are included in this study. The distinctive nature of SSB results from compliance with the Shariah but also from the high concentration of SSB positions. Therefore, this study contributes to 
prior research by analyzing the consequences of having SSB scholars with multiple memberships on the Shariah $\mathrm{Ru}$ ral Bank supervision, risk taking and counselling behavior. Finally, this study also contributes to literature regarding which role individual bank's, SSB play between the interest of shareholders, stakeholders such as depositors and regulators etc.

\section{CONCEPTUAL FRAMEWORK}

Due to the importance of Shariah compliance in Islamic banking industry, Bank Indonesia has issued guidelines to strengthen the overall Shariah compliance environment in Shariah Rural Bank. The framework is applicable to all Islamic banks i.e., Islamic Commercial Banks, Islamic Business Units and Islamic Rural Banks. The SSB prepares report which is published in the annual report of Islamic financial institution. All Islamic banking institutions are required to conduct supervision and counselling.

\section{SUPERVISION AND SHARIAH COMPLIANCE IN ISLAMIC BANKING FOR PRODUCT AND SERVICE}

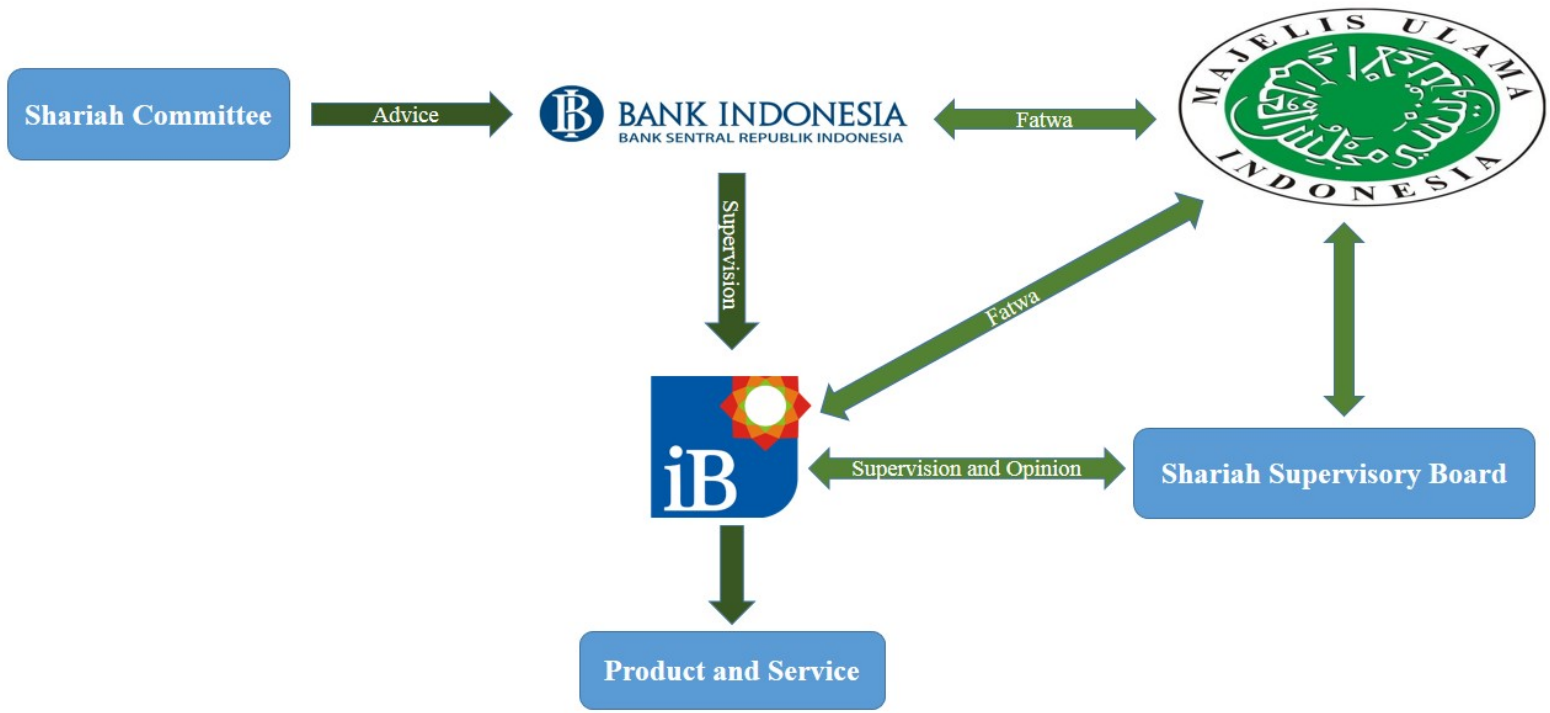

FIGURE 1. Conceptual framework (Bank Indonesia, 2012)

\section{Hypothesis}

Based on the research problemand conceptual framework above, the supervision of the Shariah Rural Bank is effective if it fulfill the principles, namely:

\section{Objective}

The supervision in Shariah Rural Bankby the SSB should be objective based on authentic, rational evidence, disclosing facts relevant to implementation work, avoiding subjective prejudices or impartial side and valid data.

\section{Independent}

The SSB must be independent. In the process and practice of supervision there should be no interference or other influence caused by the relation of brother, status of position and others.

\section{System}

The activities of supervision in Sharia Rural Bank must be implemented in the management system, specifically the planning, organizing, implementation and supervision. The supervisionmust perform effective planning, then organize and implement such monitoring plan. The final stages of supervision should be monitored, whether it has been carried out objectivly and independently.

\section{Corrective}

The supervision in Shariah Rural Bank must be able to provide benefit, to ensure corrective action in carrying out duties and functions of the management in addition to the smoothness of other supporting aspects. 


\section{RESEARCH METHOD}

The Qualitative approach was applied for solving the research questions of the research. Data were collected by semi-structured interviews. Data analysis method used by the authors in this research is qualitative method of model of Miles and Huberman (1994).

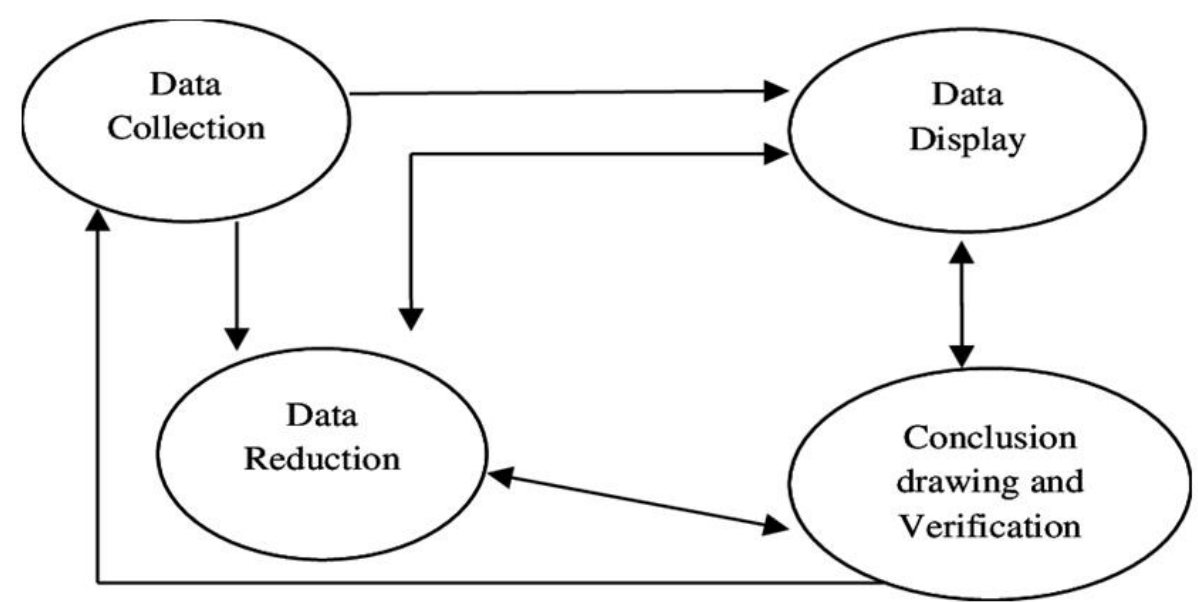

FIGURE 2. Components of data analysis (Miles \& Huberman, 1994)

The qualitative approach can preserve the chronological flow assessing the local causality and derive fruitful explanations helping the researchers go beyond initial preconceptions and frameworks.

\section{Data Reduction}

The process of selecting, focusing, simplifying, abstracting, and transforming "raw" data appearing in the written-up field notes. Data reduction occurs continuously throughout the life of any qualitatively oriented project. This is a part of analysis.

\section{Data Display}

The second major flow of analysis activity is data display. A "display" is anorganized assembly of information that permits conclusion drawing and action taking. The most frequent form of display for qualitative data has been narrative text.

\section{Conclusion Verification}

The third stream of analysis activity is conclusion drawing and verification. From the beginning of data collection, qualitative analyst is beginningto decide what things mean, regularities, patterns, explanations, possible configurations, causal flows and propositions. The final conclusions may not appear until data collection is over. Conclusion drawing is only half procedure, conclusions are also verified as the analyst proceeds. The meanings emerging from data are tested for their plausibility, their sturdiness and their "confirmability" (validity).

\section{Theory of Effectiveness}

Literally, effectiveness means influence, effect and emphasis. In general, effectiveness derived from the word effective means effect (consequently, affect and bring results). Efficiency and effectiveness is doing a job which is true (doing the right thing), while efficiency is doing work doing and doing it right (doing thing right). Effectiveness in general is related to the successful achievement of goals and objectives, while efficiency is a good comparison between the changes with the results. Thus, effectiveness and efficiency are interconnected with one another. Therefore, effectiveness is the ability to choose the right plan or the right strategy to achieve a target or high consistency of work to achieve the planned goals. It can be concluded that effectiveness is an attempt to achieve a goal by looking at the accuracy of completion of work exactly at the predetermined time. This means whether the implementation of task is considered good or not very dependent on wheather the task is solved, especially answering the question of how to implement it and how much it costs for it.

The output generated, which is not intangible is not easy to quantify. Then the measurement of effectiveness often faces difficulties. Difficulty in measuring its effectiveness is there because the achievement of outcomes is often unknown in short term but in the long run after program succeeds. So the measure of effectiveness is usually expressed qualitatively based on the quality of the form of statement only (judgment), meaning that if the quality is good, then the effectiveness is good as well (Rochaeli, 2011). 


\section{Theory of Supervision}

Various management functions implemented by the leaders are in order to achieve organizational goals. The functions of management are planning, organizing, actuating and controlling. The four management functions must be implemented by the manager on an ongoing basis, to realize the goals of organization. Supervision is a part of the management function that seeks to have a defined plan achieved effectively and efficiently. Ernie and Saefullah provide the definition of supervision is as a process determining performance measures in taking action that can support achievement of expected results according to the predetermined size (Notoatmodjo, 1992). Mathis and Jackson provides definition of supervision is process of monitoring employee's performance based on the standards to measure performance ensuring the quality of performance appraisal and retrieval of information that can make feedback communicating results to the employees (Mathis \& Jackson, 2006). The specified standard is a standard input in the form of work effortand output standards in the form of quantity, quality, cost and time. Measurement of actual performance is to see any deviation or variance between what happened in real and expected. Comparing real performance with goals or standards can result in performance similar to other standards or default performance. The latter requires management of exceptions and management of attention situations deviations between actual and expected performance. That first is enough to maintain situation. No corrective action is required. If deviation is large then corrective action needs to taken, so that the results are in accordance with the predetermined standards. Supervision can be internal, as well as, external. Internal supervision is done through self-discipline and practice of individual or group responsibility. External surveillance occurs through direct supervision or application of administrative systems such as rules and procedures (Hafidhuddin, 2003).

Implementation of activities to achieve the objectives that have been set requires supervision so that the planning that has been prepared can be done well. Supervision is very important because basically human as an object of supervision has nature of wrong and mistaken. The human beingsin an organization need to be watched. Instead of finding his fault later and punishing him, educate and guide him. The company objectives can be achieved if the supervisory function is done beforethe occurrence of deviations that is more preventing. Compared to the following surveillance action and occurrence of irregularities, the purpose of supervision is to maintain the results of the implementation of activities in accordance with the plan. The established terms and in- frastructure are actually implemented. Good oversight will create effective and efficient company goals.

\section{The SSB in Shariah Rural Bank Mitra Cahaya Indone- sia Yogyakarta}

Shariah Rural Bank Mitra Cahaya Indonesia Yogyakarta was established deed of legal No.17 on $11^{\text {th }}$ January 2008, principle licence No. 9/2095/DPbD on $12^{\text {th }}$ December 2007 and operating licence No. 10/51/KEP.GBI/DpG/2008 on $7^{\text {th }} J u l y 2008$. Since officially began operating on 1 stSeptember 2008, Shariah Rural Bank Mitra Cahaya Indonesia keeps innovating and releasing Shariah financial products such as Takaful (Shariah Insurance) and Shariah multifinance company (Al-Ijarah). The Activities of Shariah Rural Bank centered in the Office at Kaliurang Street, Km 10. No. 28, Sleman, Province Special Region of Yogyakarta.Shariah Rural Bank Mitra Cahaya Indonesia Yogyakarta is managed and handled by human resources rofessional, upholding trusts (Al-amanah) and having a deep commitment to Shariah law and Islamic economics (Idrees, 2014).

Supervisory idiomatically means to verify the implementation of Fatwa that is the issuance by the authority to find legitimate alternatives and formulas in any acts that contradict the legal requirements (Idrees, 2014). It also refers to the follow-up, testing and analysis of the works, behaviors and actions that are conducted by individuals, groups, institutions, units and others. To ensure that these transactions are in accordance with and within the requirements of the Shariah is done by using the legitimate means and indicating any irregularities and their solutions.According to the definition of SSB, there is no standard definition of the ShariahSupervisory Boardit has many definitions (Nathan Garas \& Pierce, 2010). The SSB are independent body of scholars and specialists in transactions by adding another member to the specialists in the field of Islamic financial institution who are familiar with the field of Islamic transaction. The memberof SSB is responsible for the follow-up tasks and validity of the implemented transactions in Islamic Banks and to find legitimate solutions to the irregularities. The SSB is also responsible for following up, and examining, analyzing activities, business behaviors, and operations that are carried out by Shariah Rural Bank, to ensure that they are in accordance with therules and principles of Shariah. The SSB using appropriate legitimate tools and methods with the indication of mistakes and corrections, and at the same time finds legitimate alternative (Al-'layat, 2006).

According to the SSB functions, the purpose of the SSB is to ensure that financial institutions operate in conformity with 
Shariah and is usually made up of a number of jurists who provide clarification in regards to any questions that the financial institutions may have (Rammal, 2006). Most of the researchers and Islamic finance specialists have indicated that the SSB in Islamic Banks has three main tasks. It begins with the preventive stage, which is a pre-implementation stage. Then is the curative stage which is conducted during the implementation of transaction or the project and its function is responding to the complaintsand dealing with the detected errors in the financial transaction. The last stage is called complementary stage in which role concentrates on issuing reports about the executing projects, annual reports and financial statements (Hammad, 2004).

The main role of the SSB in the Shariah Rural Bank and Islamic Financial Institutions is summarized in the participation formulating the instructions, regulations, forms of contracts, correction and development. They are also responsible for supervising the activities of the Islamic banks to ensure conformity of its works to the Islamic legal precepts and principles (Rammal, 2006). The SSB has the task of Fatwa by answering to the questions and queries, whether those inquiries are from the employees of the IB or the customers, also participating in the preparation drafts of decrees, decisions and orders presented by the bank, in addition to preparing explanatory notes thereto. The main functions of SSB are:

- Directing, reviewing and supervising the institutionals activities to ensure Shariah compliance.

- Shariahadvice and guidelines.

- Shariah approval on products and services.

- The functions of final review.

The SSB plays role in educating workers in the Islamic Banks through the patrol training courses in order to be legally qualified to accomplish their assigned work. In addition to the intervention in the resolution of dispute between the IB and others, whether the dispute is between the bank and the investors or shareholders. Finally, the role in testimony of general assembly through the submission of an annual report reflects the extent of the legality of the banks business (Al-'layat, 2006). There are other functions for the SSB that relate to the selection and hiring processes of the employes and conduct interviews to ensure that their academic qualifications are fit and proper for the Islamic banks as nature that is based on Shariah principles. Another task is tooversee projects and their implementation. The SSB functions can be also classified into two functions, supervisory functions like issuance of Fatwa and giving approval to new products, and consultative function like explaining the wayof calculating the due Zakat and offering Shariah compliant solutions during the implementation of contracts (Nathan Garas \& Pierce, 2010).

From the foregoing, it will be seen that the presence of SSB is a necessity and significant in Islamic Financial Institutions without exception because of their significant role in monitoring, regulation and investigation for the Shariah Rural Bank activities and behaviors. The SSB have another role in the development of Shariah Rural Bank products to be compatible with the principles of Shariah which is based on the abolition of usury, ambiguity and avoiding suspicions. The mere presence of SSB in Islamic banks gives sense of satisfaction and confidence to the customers of the Islamic banks, which increases their credibility level contributing indirectly to their financial performance. It is obvious that the SSB is exposed to significant challenges represented in the ability to find an expert who combines with Fiqh (Islamic Jurisprudence) and financial sciences at the same time. The Shariah Rural Bank must continue to meet the customers demands and fulfill their needs by providing more products and services within the Shariah principles and this is imposed by the SSB for another challenge.

\section{RESEARCH RESULTS AND DISCUSSION}

Implementation of Supervision and Counselling by SSB in Shariah Rural Bank Mitra Cahaya Indonesia Yogyakarta

Members of the SSB must come to Shariah Rural Bank Mitra Cahaya Indonesia Yogyakarta office once a week. Schedule of presence for the members of the SSB is self-determined by their members. It can be tailored to the activities of each member of SSB. The main activity undertaken ny the members of SSB is communicating with the management of Shariah Rural Bank Mitra Cahaya Indonesia Yogyakarta. Communication takes place in two directions between the management and the membersof SSB. For the members of SSB each arrival in Shariah Rural Bank Mitra Cahaya Indonesia Yogyakarta office will call of the management, usually represented by the head of bank operations department. The SSB is questioned of operational implementation of the bank's product related to conformity of implementation of bank's products with the principles of Shariah.

Members of the SSB open acceptance consultation with management staff usually associated with Islamic law in implementations of products, whether there is fatwa of National Shariah Board or there is no fatwa. The result of decision in the monthly meeting will be submitted to the Board of the Directors of Shariah Rural Bank Mitra Cahaya Indonesia Yogyakarta. Every month, the SSB meets with the staff of Shariah Rural Bank Mitra Cahaya Indonesia. This meet- 
ing begins with Zuhur prayers. The SSB also socializes of the latest fatwa. The National Shariah Board continues with the question and answer forum regarding fatwa of the National Shariah Board. Every year the members of the SSB in Shariah Rural Bank Mitra Cahaya Indonesia Yogyakarta attend the annual meeting with the National Shariah Board. This annual meeting discusses about the proposals of SSB socialization of the latest fatwa from the National Shariah Board and evaluation performance of the SSB. The National Shariah Board also convey to performance improvement of SSB. The main requirement for the members of the SSB is to have the ability in muamalah, economic law, and banking (Hejazi, 2005).

vWhen performing duties from the SSB proven to negligent or not performing duties properly both in terms internal supervision and external communications related to implementation fatwa and implementation of Shariah compliance, it result in losses for Shariah Rural Bank, then the SSB in this case can be said have neglected fiduciary duty in general meeting shareholders, the SSB in this case may be charged liability for loss incurred in Shariah Rural Bank. However, in this case of imposition such losses, it also necessary to separate the losses of the Shariah Rural Bank as result missteps of management procedures/policies and losses resulting from negligence in supervision the implementation principles of Shariah. The responsibility proportional of SSB as well as other Shariah Rural Bank organs, such as Board of Directors and the Board of Commissioners in accordance with the negligence/errors committed.

\section{The Effectiveness of SSB in Shariah Rural Bank Mitra Cahaya Indonesia Yogyakarta}

Performance in financial institution can be said to be effective if performance has achieved goals and standards set. The standard of work is a number of criteria that are in size performance appraisal of the SSB, which is used as a comparison and result of execution tasks of a job or position. This examination is intended to determine the extent of established system's relibility to provide adequate assurance that goals and objectives can be achieved efficiently and determine the structure already functioning as desired. The effectiveness on supervision can at least be determined by means of five point, i.e., truly independent supervisor position, supervisor position must be higher than supervised, there is a supervisory procedure standard and tested, supervisor has a high degree of honesty and supervisor has

adequate skill (knowledge). If these five things are met, then a supervision can be considered effective.
The SSB is required to have a high quality of honesty. The SSB is expected to report the results of supervision in accordance with the field facts without anything covering it. The SSB as a supervisory bank mustfeel always watched by Allah SWT. So any form of activity supervision can be really objective and reveal any small offense of Islamic banks to Shariah principles. In terms of competence, every member of SSB should have high skills, especially in the field of Islamic law and Islamic banking. The capability requirements for members ofthe SSB are most urgent absolute requirements and must be fulfilled.

The duty of the Shariah Supervisor Board is to oversee the way of Shariah Rural Bank, such as fund distribution product in Shariah Rural Bank Mitra Cahaya Indonesia Yogyakarta, the supervision of operation distribution funds in the Shariah Rural Bank Mitra Cahaya Indonesia Yogyakarta to the customers based on Shariah principles etc. The effectiveness of supervision by the SSB for the distribution of finance to customers is because. The Shariah Rural Bank Mitra Cahaya Indonesia uses principles of 5C, i.e., analysis of character, capacity analysis, analysis of capital, condition analysis and collateral analysis. As for supervision, it is conducted by the SSB to distribute finance in Shariah $\mathrm{Ru}$ ral Bank Mitra Cahaya Indonesia Yogyakarta, i.e., in internal supervision and external supervision. Internal supervision is formal and vertical supervision, meaning that supervisor is an authorized person. Internal control intends to keep off and prevent any errors in the management or the process of distribution financing. External supervision is supervision conducted by SSB.

In terms of the effectiveness of performance of the SSB as supervisors, Indryoeno said "If the SOP does not exist, the SSB has rules and has working guideline, they are set to takepart in the meetings. The SSB should not become consultant in another place. We support the SSB actively, still showing tolerance towards the activities of Shariah Rural Bank Mitra Cahaya Indonesia Yogyakarta" The current condition of Shariah Rural Bank with all its short falls and advantages must be the point of evaluation and motivation to be more able to develop Islamic banking perceived by Indonesian people. In order to improve welfare, Islamic banking is expected in the direction of future development that more can describe about Islam in the form of economics, especially in aspects of banking applications (Idrees, 2014). The presence of members in the SSB in Shariah Rural Bank Mitra Cahaya Indonesia Yogyakarta is absolutely necessary.

According to Asmuni: "The SSB is needed in Islamic banking, because $70 \%$ of employees come from non Islamic Eco- 
nomics off course it's a special burden for the SSB to do the socialization of fatwa". They must work in Islamic economics, and scheme mechanism. If the SSB controls Shariah schemes, off course the products have been translucent to Bank Indonesia. Bank Indonesia concentrates on the Shariah side itself".

Products available in Islamic banking is a very influential aspect of the development of Islamic banking in Indonesia. For that in the release product there are important things to note that gap between the needs and knowledge of society about product of the Shariah Rural Bank. Therefore, in creating a product, attention should be paid to the needs of the society. For that matter, hope the SSB in Shariah Rural Bank Mitra Cahaya Indonesia Yogyakarta in the future can create innovative islamic product Islamic and products issued in Islamic banks want to really contain Mashlahah, Thoyib and Halal (Rammal, 2006). The products in Shariah Rural Bank Mitra Cahaya Indonesia Yogyakarta should be able to operate in accordance with Shariah principles. As expected by the society a bank should be pure Islamic bank and, be spared from things that are not in accordance with the principles of Shariah. The supervision and counselling by the SSB of the products and distribution of financing in Shariah Rural Bank Mitra Cahaya Indonesia Yogyakarta are effective, because Shariah Rural BankMitra Cahaya Indonesia Yogyakarta is still operating. All functions of the SSB have been implemented and transactions have been corrected by the SSB.

\section{CONCLUSION AND RECOMMENDATIONS}

\section{Conclusion}

Based on the hypotheses and the result of the research, the conclusion of this research is as follows:

1. The activities in Shariah Rural Bank Mitra Cahaya Indonesia Yogyakarta have complied with the fatwa of National Shariah Board-Indonesian Ulema Council, Regulations of Bank Indonesia, as well as other applicable regulations. The supervision by the SSB in Shariah Rural Bank Mitra Cahaya Indonesia Yogyakarta has been effective, because supervision has achieved goals and Shariah Rural Bank Mitra Cahaya IndonesiaYogyakarta is obedient with the principles of Shariah and increases public trust.

2. The effectiveness of SSB on supervision and counselling in Shariah Rural Bank Mitra Cahaya Indonesia Yogyakarta has been effective, because industry Shariah Rural Bank Mitra Cahaya Indonesia Yogyakarta is still operating, the entire function has been applied and transaction have been corrected by the SSB. The counselling of employees in Shariah Rural Bank Mitra Cahaya Indonesia Yogyakarta is giving material about Islamic values bythe SSB every two months.

\section{Recommendations}

Although the effectiveness of SSB on supervision and counselling in Shariah Rural Bank Mitra Cahaya Indonesia Yogyakarta has been effective, the SSB must the improve quality of human resources, because still not enough human resources master the science of Islamic economic. The Shariah Rural Bank Mitra Cahaya Indonesia Yogyakarta has to provide support facilities, that the duties assumed by the SSB have no inhibiting factors in the future. The Shariah Rural Bank Mitra Cahaya Indonesia Yogyakarta must place people who are experts in the field of psychology to minimize stalled financing from the customers because it can know character of the customer itself when proposing financing.

\section{REFERENCES}

Adams, R. B., \& Ferreira, D. (2007). A theory of friendly boards. The Journal of Finance, 62(1), 217-250. doi:https://doi.org/ $10.2139 /$ ssrn. 453960

Al-'layat, A. (2006). Legitimate supervisions over the islamic banking products (Published master thesis). Nablus, Palestine.

Antara, P., Musa, R., \& Hassan, F. (2016). Theorising attitude towards islamic financing adoption in an integrative model of behavioural prediction: A proposed conceptual framework. Journal of Administrative and Business Studies, 1(1), 35-41. doi:https://doi.org/10.20474/jabs-1.1.6

Bank Indonesia. (2012). Model bisnis perbankan syariah. Retrieved from 1goo.gl/1quQro (accessed October 10, 2017)

Farook, S., \& Farooq, M. (2011). Shariah governance for Islamic finance: Challenges and pragmatic solutions (Working paper No. 1813483). Bahrain Institute of Banking and Finance, Manama, Bahrain.

Hafidhuddin, D. (2003). Manajemen syariah dalam praktik. Depok, Indonesia: Gema Insani.

Hammad, H. (2004). Shariah supervision in Islamic bank (Unpublished master thesis). The University of Jordan, Amman, Jordan.

Hejazi, A. (2005). Discussions in the Islamic banking act in the United Arab Emirates, (the rerms and general rules). Paper presented at 14th Annual Scientific Conference, Abu Dhabi, United Arab Emirates. 
Hermalin, B., \& Weisbach, M. (2001). Boards of directors as an endogenously determined institution: A survey of the economic literature (Working paper No. 8161). National Bureau of Economic Research, Cambridge, MA.

Hidayati, M. N. (2008). Dewan pengawas syariah dalam sistem hukum perbankan: Studi tentang pengawasan bank berlandaskan pada prinsip-prinsip Islam. Lex Jurnalica, 6(1), 24-37.

Idrees, M. (2014). The shariah supervision in islamic financial institutions kuwait finance house and bank islam in malaysia. Negeri Semibilan, Malaysia: Universiti Sains Islam Malaysia (USIM) Publishers.

Jundiani, J. (2009). Pengaturan hukum perbankan Syariah di Indonesia. Malang, Indonesia: UIN Maliki Press.

Madiawati, P., \& Pradana. (2016). The appeal of celebrity endorsers and halal certificates on customers' buying interest. Journal of Administrative and Business Studies, 1(1), 28-34. doi:https://doi.org/10.20474/jabs-1.1.5

Mathis, R., \& Jackson, J. (2006). Human resource management. Jakarta, Indonesia: Salemba Empat.

Miles, M. B., \& Huberman, A. M. (1994). Qualitative data analysis: An expanded sourcebook. London, UK: Sage Publication.

Nathan Garas, S., \& Pierce, C. (2010). Shari'a supervision of islamic financial institutions. Journal of Financial Regulation and Compliance, 18(4), 386-407.

Notoatmodjo, S. (1992). Pengembangan sumber daya manusia. Bandung, Indonesia: Rineka Cipta.

Rammal, H. (2006). The importance of Shari'ah supervision in Islamic financial institutions. Ownership and Control, 3(3), 204-208. doi:https://doi.org/10.22495/cocv3i3c1p5

Rochaeli, I. (2011). Fungsi dan Peranan dewan pengawas Syariah di unit usaha Syariah dikaitkan dengan pelaksanaan good corporate governance (Unpublished doctoral dissertion). University of Indonesia, Depok, Indonesia.

Umam, K. (2015). Urgensi standarisasi dewan pengawas Syariah dalam meningkatkan kualitas audit kepatuhan Syariah. Panggung Hukum, 1(2), 114-138. 